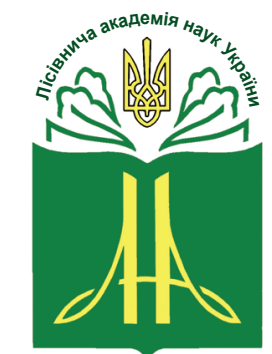

Forestry Academy of Sciences of Ukraine
Наукові праці Лісівничої академії наук України Proceedings of the Forestry Academy of Sciences of Ukraine

http://fasu.nltu.edu.ua https://doi.org/10.15421/412119

Article received 2021.01.11

Article accepted 2021.06.10

\author{
ISSN 1991-606X print \\ ISSN 2616-5015 online \\ (a) $\triangle$ Correspondence author \\ Ihor Soloviy \\ soloviy@yahoo.co.uk
}

General Chuprynka str., 103, Lviv, 79057, Ukraine

УДК 630*477:630*091

\title{
Комплексне оцінювання послуг екосистем лісоаграрного ландшафту
}

\author{
І.П. Соловій' , Т.Я. Кулешник²
}

\begin{abstract}
Метою статті є систематизація основних параметрів та алгоритму методики загального комплексного еколого-економічного оцінювання лісоаграрного ландшафту на основі теорії послуг екосистем, здійснення такого оцінювання на прикладі конкретного об 'єкта та інтерпретація його результатів. Результати оцінювання можуть бути використані для визначення формування сиенаріїв трансформачії структури землекористування лісоаграрного ландшафту. Проаналізовано значення розуміння послуг екосистем для обгрунтування рішень щзодо землекористування. Охарактеризовано особливості агроекосистем як постачальнка і споживача послуг екосистем в сучасних умовах. Запропоновано ідентифікувати та оцінювати послуги екосистем з погляду нової комплексної системи виробнищтва у ландшафті, щуо надає послуги забезпечення (продукти харчування, енергію) та підтримувальні і культурні послуги екосистем водночас. Розраховано вартість окремих ринкових і неринкових послуг екосистем та загальну вартість екосистемних послуг, наданих комбінованою системою землекористування (сільськогосподарські угіддя, пасовища та біоенергетичні плантації) для дослідної ділянки території у Жовківському районі Львівської області. У розрахунку взяті до уваги такі послуги екосистем: послуга з біологічної боротьби зі шкідниками сільськогосподарських культур; послуги з регулювання фіксації азоту і мінералізаџії грунту для сільськогосподарських культур і мікроорганізмів; послуга сприяння грунтоутворенню за допомогою дощзових черв 'яків; виробництво продуктів і кормів (сільськогосподарські культури і пасовище); виробництво сировини (біомаси); нагромадження вуглецю в грунті; гідрологічний потік у запасах підземних вод; послуга запилення рослин комахами, а також культурна послуга (ландшафтна естетика).

Ключові слова: агроекосистеми; біоенергетичні плантації; землекористування; вартість послуг екосистем; ринкові послуги; неринкові послуги.
\end{abstract}

Вступ. Природа надає широке коло послуг, які, здавалося б, є безкоштовними для людства: забезпечення підземними водами, родючим грунтом, рослинною біомасою, фотосинтезом і т.д. Певний час науковці їх так і називали - «послуги природи» (nature services - англ.), однак згодом термін «послуги екосистем» (ecosystem services - англ.) набув більшого поширення. Послуги екосистеми тракту- ють як певні вигоди, які людство отримує від екологічних процесів і функціонування екосистем (MEA, 2005).

Безперервно отримуючи вигоди від послуг екосистем - харчування, водопостачання, відпочинок, захист (Grunewald, \& Bastian, 2015), суспільство потребує кращого розуміння динаміки процесів, вигід, соціальних та економічних цінностей послуг,

\footnotetext{
Соловій Ігор Павлович - академік Лісівничої академії наук України, віце-президент ЛАН України, доктор економічних наук, професор кафедри екологічної економіки. Національний лісотехнічний університет України, вул. Генерала Чупринки, 103, м. Львів, 79057, Україна. Тел.: 032-287-03-88, +38-097-284-08-81. E-mail: soloviy@yahoo.co.uk ORCID: https://orcid.org/0000-0001-5885-6264

2 Кулешник Тарас Яркович - здобувач кафедри екологічної економіки. Національний лісотехнічний університет України, вул. Генерала Чупринки, 103, м. Львів, 79057, Україна. Тел. +38-067-777-87-47. E-mail: kuleshnyk@gmail.com ORCID: https://orcid.org/0000-0003$3386-8634$
} 
усвідомлення зв'язку між ними та економічною, екологічною та іншими секторальними політиками, практикою прийняття рішень у сфері менеджменту природних ресурсів. Теорія послуг екосистем, яка обгрунтовує сутність таких вигід для суспільства, стала основою для впровадження механізму платежів за послуги екосистем, який на практиці у багатьох країнах вже показав високу ефективність.

Міжнародні дослідження приділяють особливу увагу наслідкам, які виникають у результаті зменшення обсягів або втрати цих послуг. Так, втрати екосистемних послуг впродовж 1997-2011 рр. через зміни у землекористуванні (знеліснення, трансформація природних комплексів) було оцінено в 4,320,2 трлн дол. у рік (Costanza, Groot, Sutton, Van der Ploeg, Anderson, Farber ... Turner, 2014). Результати досліджень в Україні показали, що середньорічні збиткти від втрати екосистемних послуг грунтів за останні 50 років склали 145 дол. США/га, у тому числі - 49 дол. США/га за останні 25 років, що становить відповідно 25,6 і 8,7\% доходу від реалізації продукції рослинництва (Кучер, 2019). Варто зауважити, що глобальні оцінки, виражені в одиницях грошового обліку, корисні для висвітлення обсягів послуг екосистем, але не мають прикладного значення для прийняття рішень. Проте базові дані та моделі може бути застосовано на різних рівнях для оцінювання змін, що виникають унаслідок різних сценаріїв землекористування.

Ці надзвичайно вагомі проблеми розглядають екологи, біологи, економісти, представники інших природничих і соціальних наук. На думку низки дослідників (Raymond, Singh, Benessaiah, Turner, Nelson, Chan, 2013), залучення широкого спектру дисциплін до досліджень та оцінювання послуг екосистем дасть змогу переосмислити стосунки між людиною і довкіллям, досягти більшої гармонії в таких стосунках та інтеграції інтересів зацікавлених сторін, відігравати важливішу роль у керуванні політичними процесами, наданні відповідних соціальних та екологічних даних політикам для прийняття обгрунтованих рішень.

Їхні підходи, термінології та методологічні особливості настільки ж відмінні, як і самі дисципліни. У цьому контексті постає питання: як оцінити ефективність природи і чи всі екосистемні послуги можна кількісно визначити, монетизувати і забезпечити їхню доступність у майбутньому? До найактуальніших необхідно віднести питання ідентифікації, класифікації, картування та оцінювання послуг екосистем, пошук способів інтеграції результатів цих оцінювань у секторальні політики та механізми прийняття рішень.

Земля - основа життя людини, головний засіб i просторовий базис виробництва продовольства i сировини, один з основних складників добробуту. Однак прийняття рішень у сфері землекористування далеко не повною мірою бере до уваги усі аспекти цінності землі для добробуту, оскільки механізми прийняття рішень ігнорують значну частину послуг екосистем.
Сучасне сільське господарство достатньо успішне в аспекті забезпечення продовольчою та іншою продукцією для задоволення потреб ринку і населення. Поряд 3 цим, надання цих послуг часто досягається за рахунок отримання інших життєво важливим послуг, серед яких регулювання клімату, охорона підземних вод, боротьба 3 сільськогосподарськими шкідниками, контроль ерозії грунтів, збереження біорізноманіття. Розуміння цінностей послуг екосистем може стати основою рішень щодо землекористування.

За розрахунками (Porter, Costanza, Sandhu, Sigsgaard, \& Wratten, 2009) економічна вартість прямих і непрямих вигід від послуг глобальної екосистеми складає 125 трлн \$ USD на рік, що в декілька разів більше від світового валового національного продукту. Однак, використання цих послуг для забезпечення довгострокової стійкості екосистем та їхня здатність генерувати суспільне багатство недооцінені. Хоч деякі з послуг екосистем продаються на ринках послуг екосистем, але більшість 3 них на сьогодні є неринковими і не мають визначеної ціни. Реальна цінність послуг екосистем є надзвичайно високою, оскільки від них безпосередньо залежить саме людське існування.

Актуальність оцінювання послуг екосистем лісосаграрного ландшафту зумовлена його важливістю для поглиблення розуміння внеску широкого кола послуг для добробуту та екологічної стійкості ландшафту, використання цих результатів для формування сценаріїв майбутнього землекористування.

Об'скти та методика дослідження. Об ' $\epsilon$ ст дослідження - набір послуг екосистем лісоаграрного ландшафту. Предмет досліджень - теоретичні і прикладні аспекти оцінювання послуг екосисистем лісоаграрного ландшафту.

Мета роботи полягає в систематизації основних параметрів і визначенні алгоритму методики загального комплексного еколого-економічного оцінювання лісоаграрного ландшафту на основі теорії послуг екосистем, здійснення такої оцінки на прикладі конкретного об'єкту, інтерпретація його результатів.

Новітні комбіновані системи виробництва харчування в агроекосистеі є на лише джерелом продуктів харчування. Лісові захисні смуги, плантації швидкорослих дерев та інші лісонасадження в агроланлшафті водночас можуть постачати енергію 3 деревної біомаси. Виробничий досвід показав, що в Україні можна успішно створювати і вирощувати «енергетичні плантації» верби і тополі 3 метою отримання біомаси, яку можна використовувати як біопаливо (Дебринюк, Соловій 2012). Послуги екосистем ідентифіковано та оцінено саме 3 погляду такої нової комплексної системи виробництва у ландшафті, як постачання продуктів харчування, енергії та послуг екосистем водночас (Wratten, Sandhu, Cullen, \& Costanza, 2013).

Система CFEES (Combined Food and Energy Ecosystem Services), на якій базується наша робота, була запропонована 3 метою створення агроеко- 
систем, що спеціалізується на виробництві відновлюваної біомаси, а також на вирощувані та зборі врожаю сільськогосподарських культур харчового призначення і кормів. Біоенергетичний компонент представлений смугами швидкорослих дерев (верби та вільхи), які посаджені ортогонально (прямокутно) на краях полів із зерновими сільськогосподарськими культурами.

Економічну вартість послуг екосистем, пов'язаних із системою CFEES, оцінено стосовно кожної 3 послуг і розраховано для трьох категорій: сільськогосподарські культури, біоенергетичні плантації і пасовища у системі CFEES. Повну економічну вартість послуг екосистеми розраховано сумуванням

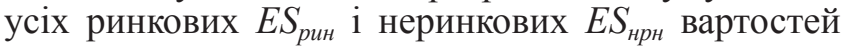
для кожної категорії:

$$
E S_{\text {заг }}=E S_{\text {рин }}+E S_{\text {нрн }}
$$

або

$$
E S_{\text {заг }}=\sum_{\mathrm{i}=1}^{9} E S_{i}
$$

де $E S_{\text {заг }}$ охоплює такі послуги: ES1 - послуга 3 біологічної боротьби з шкідниками; ES2 - послуги з регулювання фіксації азоту і мінералізацію для сільськогосподарських культур і мікроорганізмів; ES3 - послуга грунтоутворення за допомогою дощових черв'яків; ES4 - виробництво продуктів i кормів (сільськогосподарські культури і пасовище);
ES5 - виробництво сировини (біомаси); ES6 - нагромадження вуглецю в грунті; ES7 - гідрологічний потік в резервах підземних вод; ES8 - ландшафтна естетика; ES9 - запилення дикими комахами.

$E S_{\text {рин }}$ у рівнянні 1.1 включає ринкову економічну вартість виробництва продовольства, кормів (ES4) i біомаси (ES5), оскільки це єдині категорії, в яких фермери торгують продуктами на ринку. Решта значень $E S_{\text {заг }}$ У рівнянні 1.1 походить із неринкових послуг (Porter et al., 2009).

Методи, які оцінюють ї економічну вартість описано нижче. У досліджені, як приклад, здійснено комплексну еколого-економічну оцінку території Мацошинської сільської ради Жовківського району Львівської області. Запропонована система CFEES складається з 680,7 га ріллі (ячмінь і пшениця), пасовища - 79,1 га і насаджень - 41,5 га.

Дані використовували з офіційних джерел (Державна служба статистики України, 2021), а ринкові ціни на окремі матеріали - на основі усереднених цін інтернет-магазинів.

Результати дослідження. Особливість агроекосистем полягає в тому, що вони $\epsilon$ «високоінженерними» системами, які призначені для виробництва продуктів харчування та сировини для промислового використання. Проте вони є водночас споживачами і виробниками послуг екосистем. Концепція функціонування послуг агроекосистем зображена на рис. 1.

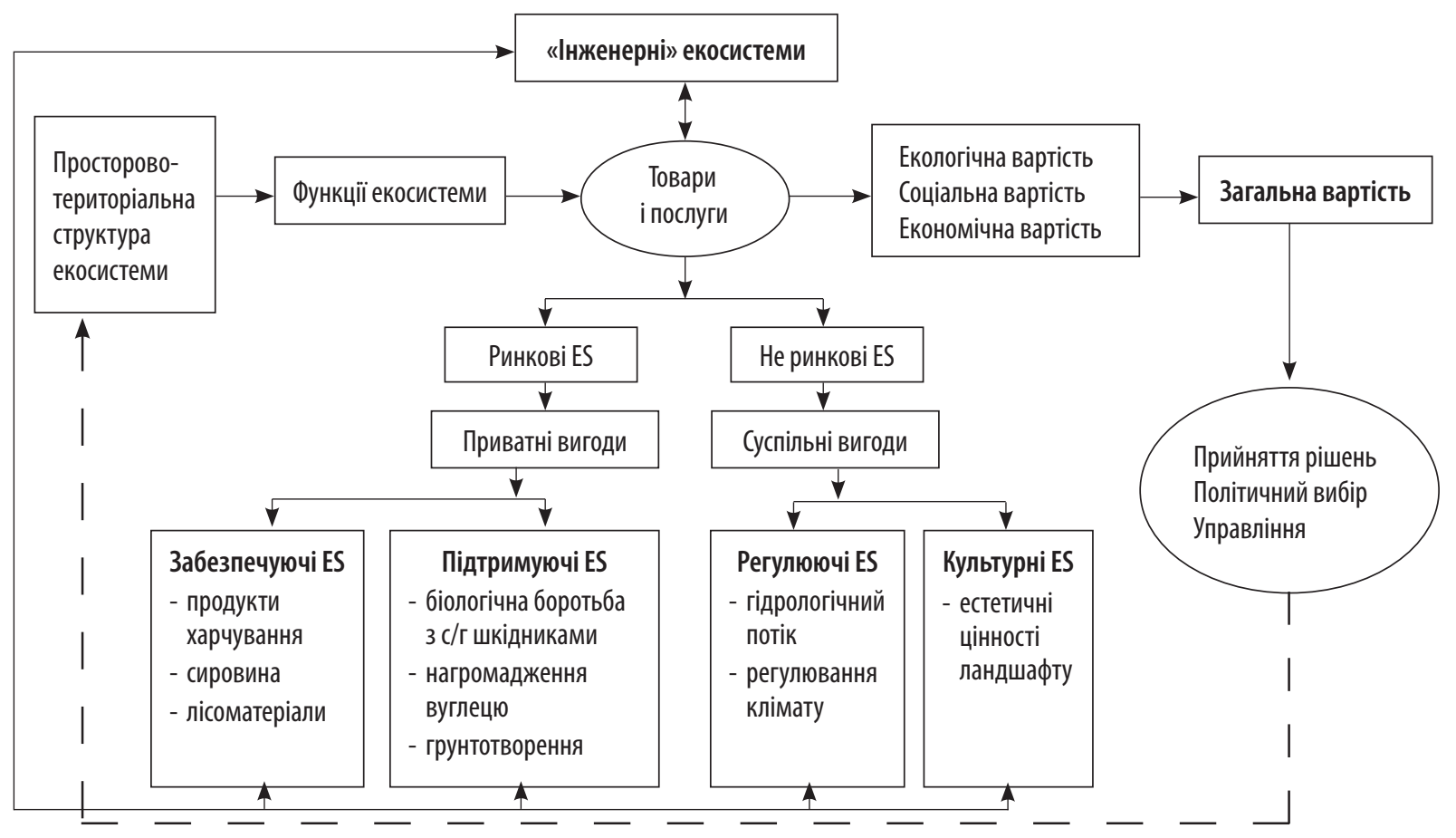

Рис. 1. Концептуальна схема функціонування послуг екосистем (на основі MEA, 2005)

Менеджмент сільськогосподарських ландшафтів може мати негативний або позитивний вплив на постачання послуг екосистем за різних агрономічних систем землеробства. Послуги екосистем у сільськогосподарських ландшафтах мають соціальну, економічну та екологічну вартість. Агроекосис- теми надають багато таких послуг: суспільні (естетичні цінності, поглинання вуглецю, надання культурних послуг), а також такі послуги, які можна розглядати і як приватні з погляду землевласника (боротьба з ерозією грунтів, біологічна боротьба зі шкідниками і хворобами, грунту, вода) вигоди. 
Ці вигоди мають економічну цінність для землевласників, тому існує можливість торгівлі ними на ринку. 3 розвитком ідеї послуг агроекосистем зростає зацікавленість до використання сільськогосподарських земель для виробництва біопалива (FAO, 2007). Такі вимоги можуть поєднати нові системи первинного виробництва, які гарантують чисте позитивне поглинання вуглецю, є низькозатратними, $\mathrm{i}$ забезпечують суспільство комплексом послуг екосистем.

Оцінювання в рамках системи CFEES дало такі результати стосовно кожної з розглянутих екосистемних послуг.

Біологічна боротьба з сільськогосподарськими шкідниками (ES1). Економічну вартість заходів біологічної боротьби з шкідниками оцінювали за допомогою методу уникнення витрат, повязаних із застосуванням пестицидів. Базуючись на їхній вартості в Україні та нормах витрат, економічна вартість склала 3219 грн на 1 га.

Азоторегулювання (ES2). Економічна оцінка азоторегулювання бере до уваги дві форми азоту, які використовують мікроорганізми і рослини (Bjorklund, Limburg, \& Rydberg, 1999). Щоб визначити вартість ES2 для окремих сільськогосподарських культур, пасовищ і біоенергетичних плантацій системи CFEES, повна вартість ES2 повинна бути помножена на 0,3. В окремих компонентах CFE системи підрахована необхідна кількість мінерального добрива (кг на 1 га): 2771 (пасовища), 143 (с.-г. культури), 10 (біоенергетичні плантаціï) (Porter et al., 2009). Bpaховуючи ціну амонійно-нітратного добрива в Україні, економічна вартість даної послуги екосистеми становитиме (грн на 1 га): 4189,7 для пасовища, 216,2 для с.-г. культур та 15,12 - для біоенергетичних плантацій. Повна фіксація азоту мікроорганізмами складає (кг на 1 га): 690 для пасовищ, 345 кг для с.-г. культур і 24 кг для плантацій (Bjorklund et al., 1999). Отже, економічна вартість цієї послуги екосистеми для сільськогосподарських культур становить 737,9, для пасовищ - 5233,0, для біоенергетичних плантацій $-51,4$ грн.

Ірунтоутворення (ES3). Грунтоутворення вважається тісно пов'язаним 3 діяльністю дощових черв'яків, тому залежить від густоти (щільності) дощових черв'яків на одиниці площі. Економічна вартість дощових черв'яків у грунтоутворенні була розрахована на основі припущення, що середня біомаса дощового черв'яка становить 0,2 г, і що 1000 кг дощових черв'яків формує 1000 кг грунту на 1 га впродовж року (Porter et al., 2009).

Кількість черв'яків у становить складає 5 млн шт. на 1 га для пасовищ та біоенергетичних плантацій, і 2 млн шт. на 1 га сільськогосподарських угідь (Посудін, 2012). Тобто черв'яки впродовж року виробляють 1000 кг та 400 кг грунту на гектарі пасовищ (плантацій) та сільськогосподарських угідь відповідно. Взявши за основу чорнозем, врахувавши його питому вагу в $1 \mathrm{~m}^{3}$ (Шкварук, Делеменчук, 1976) та середньо-ринкову ціну (350 грн/т) визнача$€ м 0$, що економічна вартість за рік цієї неринкової послуги екосистеми становить 350 грн/га для пасовищ і біоенергетичних плантацій та 170 грн/га для сільськогосподарських культур.

Виробництво харчових продуктів (ES4). Урожайність сільськогосподарських культур і пасовищ взято за 2019 р., а економічну вартість розраховано, як виручку від реалізації цих продуктів за ринковими цінами. У результаті обчислень, економічна вартість сільськогосподарських культур складає 8191,32 , а для пасовища - 1240 грн на 1 га.

Виробництво сировини (ES5). Біоенергетичні плантації забезпечують деревину для енергії, i їхню економічну вартість розраховано як виручку за деревину для виробництва енергії, що становила 5362 грн на 1 га за рік (Соловій, Перебора, 2009).

Нагромадження вуглецю (ES6). Кількість рослин і кореневих залишків оцінено для кожної категорії CFEES з урахуванням врожайності, а також на основі твердження, що вуглець становить 40\% від їхньої маси. Економічну вартість нагромадженого вуглецю в урожаї і кореневих залишках розраховано на основі ціни 1 т нагромадженого вуглецю. Отже, економічна вартість для кожної категорії CFEES становить (грн на 1 га): 1880 для сільськогосподарських культур, 4200 - для пасовищ і 21840 - для біоенергетичних плантацій.

Гідрологічні послуги (ES7). Економічну вартість цієї послуги екосистем розраховано на підставі методу оцінювання кількості опадів. Вартість застосування води розраховано в обсязі 160 грн за 100 мм води на 1 га. Враховуючи кількість опадів на рік у цьому регіоні, економічна вартість послуги екосистеми становить 104000 грн на 1 га для кожної категорії.

Естетичні послуги ландшафтів (ES8). Послуга розрахована за допомогою методу умовного оцінювання і стосується готовності платити за покращення i підтримання естетичного вигляду ландшафтів. У дослідженні взяло участь 100 осіб. Результати опрацювання отриманих даних свідчать, що сума, яку б вони погодились вносити за рік для покращення естетичного вигляду полів, зайнятих під сільськогосподарські культури, становить 50 грн, за пасовища - 75 грн., а за лісові ландшафти - 100 грн. Середній вік опитаних становить 40 років. Більшість респодентів, які брали участь у дослідженні, мають вищу освіту.

Запилення (ES9). Економічне значення цієї послуги екосистеми оцінювали за допомогою прямих витрат на придбання (оренду) бджолиних вуликів/ сімей на період запилення. Добре запилені культури дають більшу кількість продукції кращої якості і вона є привабливішою для споживача. На 1 га комахозапильних рослин потрібно розмістити від 2 до 8 сімей медоносних бджіл (Ільмінська, 2020). Наприклад, 1 га ріпаку потребує 4 бджолосім’ї або ж вдвічі меншу кількість подібних (диких) бджіл. Для запилення 1 га саду потрібно або дві сім’ї (2070 тис. особин) медоносних бджіл, або 530 самок осмії (дика бджола). Якщо територія сприяє проживанню достатньої кількості спеціалізованих ди- 
ких запилювачів, то взагалі немає потреби додаткового запилення медоносними бджолами (Ільмінська, 2020). У зв'язку з цим, ми розглядаємо послуги комбінованої системи CFEES, в яку входять території під пасовища та біоенергетичні плантаціï, що вони $\epsilon$ природним середовищем існування диких запилювачів. Відповідно, немає потреби в окремому придбанні або оренді вуликів медонос- них бджіл. Вартість оренди бджолиної сім’ї на період цвітіння в середньому становить 550 грн (Карпенко, 2019). Отже, вартість цієї послуги оцінюємо, виходячи 3 економії на оренді в середньому п'яти бджолиних сімей на 1 га, що становить 2750 грн. як для 1 га пасовищ, так і для 1 га біоенергетичних плантацій. Зведені результати представлені у таблиці.

Таблиия

\section{Розрахункова вартість послуг екосистеми сільськогосподарських культур, пасовищ та біоенергетичних плантацій, грн/га}

\begin{tabular}{cccc|cccc}
\hline \multirow{2}{*}{$\begin{array}{c}\text { Послуги } \\
\text { екосистеми }\end{array}$} & \multicolumn{2}{c|}{ Неринкові послуги екосистеми } & \multicolumn{3}{c}{ Ринкові послуги екосистеми } & С.-г \\
\cline { 2 - 6 } & культури & Пасовища & $\begin{array}{c}\text { Біоенергетичні } \\
\text { плантації }\end{array}$ & $\begin{array}{c}\text { С.-г. } \\
\text { культури }\end{array}$ & Пасовища & $\begin{array}{c}\text { Біоенергетичні } \\
\text { плантації }\end{array}$ & Всього \\
\hline ES1 & 3219 & - & - & - & - & - & 3219 \\
\hline ES2 & 737,86 & 5233,03 & 51,41 & - & - & - & 6022,3 \\
\hline ES3 & 140,0 & 350,0 & 350,0 & - & - & - & 840,0 \\
\hline ES4 & - & - & - & 8191,32 & 1240 & - & 9431,32 \\
\hline ES5 & - & - & - & - & - & 5362 & 5362 \\
\hline ES6 & 350,4 & 672 & 8736 & - & -- & - & 9758,4 \\
\hline ES7 & 1040 & 1040 & 1040 & - & - & - & 3120 \\
\hline ES8 & 50 & 75 & 100 & - & - & - & 225 \\
\hline ES9 & 0 & 2750 & 2750 & - & - & - & 5500 \\
\hline Bсього & 5537,26 & 10120,03 & 13027,41 & 8191,32 & 1240 & 5362 & 43478,02 \\
\hline
\end{tabular}

Загальна вартість екосистемних послуг, надана комбінованою системою землекористування (сільськогосподарські угіддя, пасовища та біоенергетичні плантації) становить 43478,02 грн на 1 га.

За даними зведеної діаграми (рис. 2), найбільшу вартість серед неринкових послуг має послуга нагромадження вуглецю (ES6), а серед ринкових виробництво харчових продуктів (ES4).

Висновки і дискусія. Один із підходів до послуг екосистем полягає у визначенні функцій i послуг в масштабі ландшафту 3 метою інтегрування цієї концепції для вирішення питань землекористування. Усвідомлення того, що ландшафти забезпечують безліч функцій та існує можливість їхнього вибору 3-поміж багатьох видів землекористування, зумовлює збільшення дослідницької зацікавленості до питання зв'язків між землекористуванням і функціями ландшафту (Соловій, Кулешник 2011).

На думку деяких дослідників, включення майбутніх послуг екосистем до політики просторового планування є критично важливим (Gomes et al., 2021). Тому в економічних розрахунках інвестиційних проектів потрібно врахувати цінності всіх екосистемних послуг, що надають земельні ресурси та грунтовий покрив (очищення води, поглинання вуглецю, регулювання мікроклімату, екологічно безпечні умови проживання та екологічно чис- ті продукти харчування тощо) (Стойко, Стадницька, 2020).

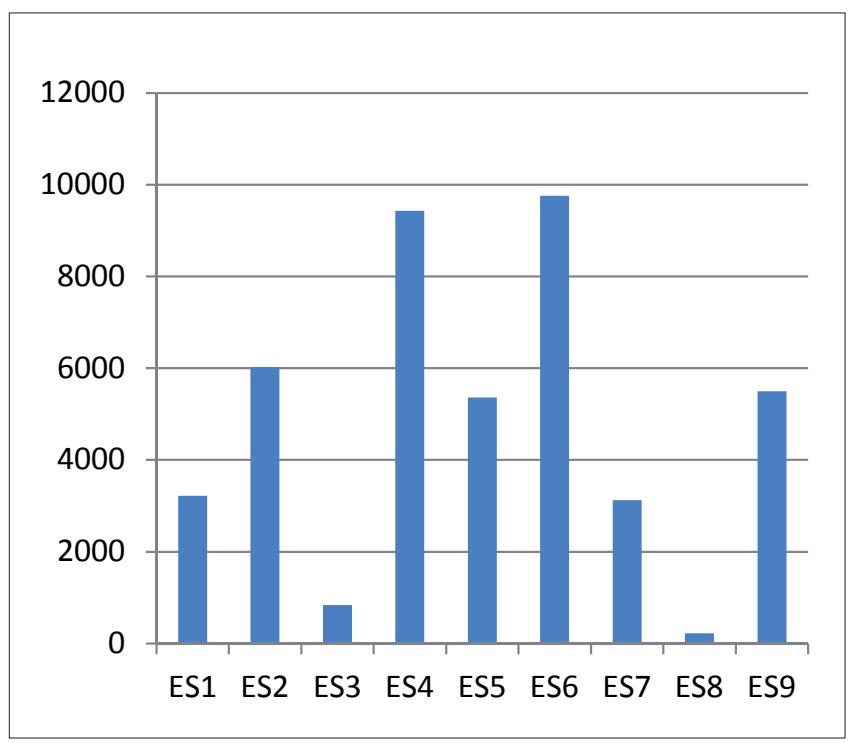

Рис. 2. Загальна вартість послуг екосистем, наданих комбінованою системою землекористування

Агроекосистеми є «високоінженерними» системами, які не лише споживають, але й виробляють послуги екосистем. Деякі послуги продаються на ринку послуг екосистем, але більшість 3 них 
$€$ неринковими, оскільки не мають чітко визначеної ціни. Сучасне індустріальне сільське господарство має у полі зору лише вузький спектр послуг агроекосистем, а саме - продовольство і промислову сировину. Однак розширити спектр послуг можливо шляхом підтримки і посилення дії інших важливих послуг екосистем, таких як регулювання клімату, охорона вод та збереження біорізноманіття, які є необхідними для підтримання людського життя та суспільного добробуту.

Оцінювання послуг агроекосистем, як і оцінювання послуг лісових екосистем, беручи до уваги зростання їхньої вагомості для виживання і добробуту людства, стає все важливішою темою наукових досліджень, як з теоретичного, так і $з$ науковопрактичного (прикладного) поглядів.

Загальна вартість екосистемних послуг, наданих комбінованою системою землекористування на дослідному об'єкті у Жовківському районі Львівської обл. площею 801,3 га склала 43478,02 грн на 1 га. Найбільшу вартість серед оцінених неринкових послуг екосистеми отримала послуга нагромадження вуглецю, а серед ринкових - виробництво харчових продуктів.

Структура лісоаграрного землекористування, за якої можна отримати найвищу еколого-економічну оцінку, поєднує сільськогосподарські культури, пасовища та біоенергетичні плантації. Оптимальність поєднання цих елементів ландшафту може бути одним із критеріїв сталості землекористування в агроландшафтах.

\section{Список літератури}

Державна служба статистики України (2021). Офіційний сайт (Електронний ресурс). [State Statistics Service of Ukraine (2021). Official site (Electronic resource). Retrieved from www.ukrstat.gov.ua] (in Ukrainian)

Дебринюк Ю. М., Соловій І. П. (2012). Плантаційне лісовирощування: еколого-економічні, технологічні та лісівничі особливості. Наукові прачі Лісівничої академії наук України, 10, 48-54. [Debryniuk, Yu. M., Soloviy, I.P. (2012). Forest plantations: environmental, economic, technological and silvicultural aspects. Proceedings of the Forestry Academy of Sciences of Ukraine, 10, 48-54. Retrieved from http://fasu.nltu.edu. ua/index.php/nplanu/issue/view/13] (in Ukrainian)

Ільмінська Л. (2020). Запилення рослин комахами. Екосистемні послуги. Ukrainian Nature Conservation Group, 2020. [Ilminska, L. (2020). Pollination of plants by insects. Ecosystem services. Ukrainian Nature Conservation Group, 2020. Retrieved from https://uncg. org.ua/zapylennia-roslyn-komakhamy/] (in Ukrainian)

Карпенко А. (2019). Бджолономіка: як працює ринок платного запилення. Agravery. [Karpenko, А. (2019). Beekeeping-economy: how the paid pollination market works. Agravery. Retrieved from https://agravery. com/uk/posts/show/bdzolonomika-ak-pracue-rinok-platnogo-zapilenna] (in Ukrainian)
Кучер А.В. (2019). Стратегічні напрями розвитку низьковуглечевого землекористування як запоруки стійкості до змін клімату: монографія. Харків: ФОП Бровін О. В. [Kucher A. V. (2019). Strategic directions of low-carbon land use development as a guarantee of resilience to climate change: monograph. Kharkiv: FOP Brovin O. V.] (in Ukrainian)

Посудін Ю.І. (2012). Моніторинг довкілля 3 основами метрології- Київ. 432 с. [Posudin Yu. I. (2012). Environmental monitoring with the basics of metrology. Kyiv. Retrieved from: http://ekmair.ukma. edu.ua/handle/123456789/1568 2] (in Ukrainian)

Соловій І. П. Кулешник Т. Я. (2011). Трактування ключових термінів концепції послуг екосистем 3 огляду на еколого-економічні дослідження ландшафтів. Наукові праці Лісівничої академії наук України, 9, 174-178. [Soloviy, I.P., Kuleshnyk, T. Ya. (2011). Interpretation of ecosystem services concept key terms from the perspective of ecological economic studies at landscape level. Proceedings of the Forestry Academy of Sciences of Ukraine, 9, 174-178. Retrieved from http://fasu.nltu.edu.ua/index.php/nplanu/ issue/view/14] (in Ukrainian)

Соловій І.П., Перебора С.В. (2009). Екологоекономічні та лісополітичні аспекти розвитку плантаційного лісовирощування. Науковий вісник Національного лісотехнічного університету України, 19.4, 61-67 [Soloviy I.P., Perebora S.V. (2009). Ecological, economic and forest policy aspects of plantation forestry development. Scientific Bulletin of Ukrainian National Forestry University, 19.4, 61-67. Retrieved from https://nv.nltu.edu.ua/Archive/2009/19_4/index.htm] (in Ukrainian)

Стойко Н. Є., Стадницька О.В. (2020). Ефективне використання деградованих і малопродуктивних сільськогосподарських земель: аспект планування. Украӥнський журнал прикладної економіки, 5(1), 333-341. [Stoyko, N.E., Stadnytska, O. V. (2020). Effective use of degraded and unproductive agricultural lands: planning aspect. Ukrainian Journal of Applied Economics, 5(1), 333-341. https://doi.org/10.36887/2415-8453-20201-39] (in Ukrainian)

Шкварук М.M., Делеменчук М.I. (1976). Грунтознавство. Київ: Вища школа. 320 с. [Shkvaruk M. M., \& Delemenchuk M.I. (1976). Pedology. Kyiv, Vyshcha Shkola. Retrieved from https://collectedpapers. com.ua/category/soil_science] (in Ukrainian)

Bjorklund, J., Limburg, K.E., \& Rydberg, T. (1999). Impact of production intensity on the ability of the agricultural landscape to generate ecosystem services: an example from Sweden. Ecological Economics, Volume, 29(2), 269-291. https://doi.org/10.1016/ S0921-8009(99)00014-2

Costanza, R., Ervin, D., Bluffstone, R., Boyd, J., Brown, D., Chang, ... Yeakley, V. (2011). Valuing Ecological Systems and Services. F1000 Biology Reports, 3(14). 10.3410/B3-14.

Costanza, R., Groot, R., Sutton, P., Van der Ploeg, S., Anderson, S., Farber, S. ... Turner, R. (2014). 
Changes in the global value of ecosystem services. Global Environmental Change, 26, 152-158. https:// doi.org/10.1016/j.gloenvcha.2014.04.002

Daily, G., Soderqvist, T., Aniyar, S., Arrow, K., Dasgupta, P., Ehrlich, P. R., ... Walker, B. (2000). The value of nature and the nature of value. Science, 289 (5478), 395. https://doi.org/10.1126/ science.289.5478.395

FAO (2007). The State of Food and Agriculture: Paying Farmers for Environmental Services. FAO Agriculture Series, 38, Rome

Gomes, E., Inácio, M., Bogdzevič, K., Kalinauskas, M., Karnauskaite, D., \& Pereira P. (2021). Future land-use changes and its impacts on terrestrial ecosystem services: A review. Science of The Total Environment, 781, 146716, https://doi.org/10.1016/j. scitotenv.2021.146716

Grunewald, K., \& Bastian, O. (2015). Ecosystem Services (ES): More Than Just a Vogue Term? In K. Grunewald, O. Bastian (Eds.), Ecosystem Services - Concept, Methods and Case Studies (pp. 1-11). Berlin, Heidelberg: Springer-Verlag. https://doi.org/ 10.1007/978-3-662-44143-5

MEA (2005). Ecosystems and Human Well-Being: Synthesis. Washington, DC: Island Press

Porter, J., Costanza, R., Sandhu, H., Sigsgaard, L., \& Wratten, S. (2009). The Value of Producing Food, Energy, and Ecosystem Services within an Agro Ecosystem. AMBIO: A J. of the Human Environment, 38(4), 186-193. https://doi.org/10.1579/0044-744738.4.186

Raymond, C.M., Singh, G.G., Benessaiah, K., Turner, N.J., Nelson, H., \& Chan, K.M.A. (2013). Engaging multiple disciplines in ecosystem services research and assessment. BioScience, 63(12), 913914. https://doi.org/10.1525/bio.2013.63.12.18

Wratten, S., Sandhu, H., Cullen, R., \& Costanza, R. (2013). Ecosystem Services in Agricultural and Urban Landscapes. Queensland, Australia: WileyBlackwell

\section{Comprehensive evaluation of ecosystem services in forest-agricultural landscape}

\section{Soloviy', T. Kuleshnyk ${ }^{2}$}

The aim of the article is to systematize the main parameters and the algorithm of the methodology for

Ihor Soloviy - Full Member of the Forestry Academy of Sciences of Ukraine, vice-president of the Ukrainian Forestry Academy of Sciences, Doctor of Economic Sciences, Professor of the Department of Ecological Economics. Ukrainian National Forestry University, 103 General Chuprynka str., Lviv, 79057, Ukraine. Tel.: 032-287-03-88, +38-097-284-08-81. E-mail: soloviy@yahoo. co.uk ORCID: https://orcid.org/0000-0001-5885-6264

Taras Kuleshnyk - PhD Candidate, Department of Ecological Economics, Ukrainian National Forestry University, 103 General Chuprynka str., Lviv, 79057, Ukraine. Tel.: +38-067-777-87-47. E-mail: kuleshnyk@gmail.com ORCID: https://orcid.org/00000003-3386-8634 the general comprehensive ecological and economic evaluation of the forest-agrarian landscape in the context of determining the directions for improving the mechanism for transforming the structure of land use on the basis of the ecosystem services theory.

The importance of understanding ecosystem services for informing decisions about land use discussed. Involving a wide range of disciplines in research and evaluation of ecosystem services will make it possible to rethink and redesign the relationship between man and the environment, achieve greater harmony in such relationships and integrate multiple stakeholders interests, play a key role in managing policy processes, providing relevant social and environmental data to policymakers.

The main features of agroecosystems as a supplier and consumer of ecosystem services in modern conditions are characterized. Agroecosystems considered as «highly engineered» systems that are not only consumers but also producers of ecosystem services. Some ecosystem services are sold at the ecosystem services market, but most of them are nonmarket because they do not have a clearly defined price. Modern industrial agriculture has in view a narrow range of services of agroecosystems, namely food and industrial raw materials. But it is possible to expand this range of services by supporting and enhancing other important ecosystem services, such as climate regulation, water protection and biodiversity conservation, which are necessary to support human life and social well-being.

It is proposed to identify and evaluate ecosystem services from the point of view of a new integrated production system in the landscape that supplies food, energy and ecosystem services at the same time. The value of individual market and non-market ecosystem services and the total value of ecosystem services provided by the combined land use system (agricultural land, pastures and bioenergy plantations) calculated. The following ecosystem services are taken into account in the calculation: service on biological control of agricultural pests; services for the regulation of nitrogen fixation and soil mineralization for crops and microorganisms; service to promote soil formation with the help of earthworms; production of food and fodder (crops and pasture); production of raw materials (biomass); accumulation of carbon in the soil; hydrological flow in groundwater reserves; insect pollination service for plants, as well as cultural service (landscape aesthetics).

The total cost of ecosystem services provided by the combined land use system (agricultural lands, pastures and bioenergy plantations) calculated for the case study area (Zhovkva district, Lviv oblast, Ukraine). Among the estimated non-market ecosystem services the service of carbon accumulation received the highest value, and among the market ones - the production of food products.

The structure of forest-agricultural landscape for which the highest ecological and economic value can be obtained is a combination of crops, pastures and 
bioenergy plantations. The optimal combination of these landscape elements can serve as one of the criteria for the land use sustainability.

Key words: agroecosystems; bioenergy plantations; land use; value of ecosystem services; market services; non-market services.

\section{Комплексная оценка услуг экосистем лесоаграрного ландшафта}

\author{
И.П. Соловий ${ }^{1}$ Т.Я. Кулешник ${ }^{2}$
}

Целью статьи является систематизация основных параметров и алгоритма методики общей комплексной эколого-экономической оценки лесоаграрного ландшафта в контексте определения направлений совершенствования механизма трансформации структуры землепользования на основании теории услуг экосистем. Проанализированы значение понимания услуг экосистем для обоснования решений относительно землепользования. Охарактеризованы особенности агроэкосистем как поставщика и потребителя услуг экосистем в современных условиях.
Предложено идентифицировать и оценивать услуги экосистем с точки зрения новой комплексной системы производства в ландшафте, что поставляет продукты питания, энергию и услуги экосистемы одновременно. Рассчитано стоимость отдельных рыночных и нерыночных услуг экосистем и общую стоимость экосистемных услуг, предоставляемых комбинированной системой землепользования (сельскохозяйственные угодья, пастбища и биоэнергетические плантации).

Ключевые слова: агроэкосистемы; биоэнергетические плантации; землепользование; стоимость услуг екосистем; рыночные услуги; нерыночные услуги.

Соловий Игорь Павлович - академик Лесной академии наук Украины, вице-президент ЛАН Украины, доктор экономических наук, профессор кафедры экологической экономики. Национальный лесотехнический университет Украины, ул. Генерала Чупринки, 103, г. Львов, 79057, Украина. Тел.: 032-287-03-88, +38-097-284-08-81. E-mail: soloviy@, yahoo.co.uk ORCID: https://orcid.org/0000-0001-5885-6264

2 Кулешник Тарас Яркович - соискатель кафедры экологической экономики. Национальный лесотехнический университет Украины, ул. Генерала Чупринки, 103, м. Львов, 79057, Украина. Тел.: +38-067-777-87-47. E-mail: kuleshnyk@gmail.com ORCID: https://orcid.org/0000-0003-3386-8634 